\title{
KEHIDUPAN PASCA KONFLIK DAN KETEGANGAN RELASI SOSIAL: SUATU ANCAMAN KEHANCURAN SOCIAL CAPITAL TRUST
}

\author{
M. Saleh Laha' ${ }^{1}$, Fatmawada Sudarman ${ }^{2}$, Moh. Nutfa $^{3}$ \\ ${ }^{1}$ Dosen/Institut Ilmu Sosial dan Ilmu Politik \\ YAPIS Biak \\ ${ }^{2}$ Dosen/Institut Ilmu Sosial dan Ilmu Politik \\ YAPIS Biak \\ ${ }^{3}$ Peneliti Konflik/ Direktur Lembaga Pusat Studi Sosial dan Kebijakan Daerah (PS2KD), \\ Sulawesi Tengah
}

\begin{abstract}
ABSTRAK
Realitas sosial selalu tidak lepas dari konflik dan ketegangan relasi sosial. Tulisan ini bertujuan mendeskripsikan dua studi kasus, yaitu kehidupan sosial masyarakat Poso pasca konflik dan relasi sosial antar etnik di Biak Papua yang diteliti secara kuantitatif dan kualitatif. Hasil penelitian menemukan bahwa masyarakat Poso faktual masih terikat oleh ingatan konflik dimasa lalu yang menghambat proses damai sejati. Sedangkan relasi sosial antara etnik pribumi dengan etnik pendatang ditanah Biak Papua turut mengalami ketegangan sosial akibat dari kompetisi ekonomi sehingga mematikan nilai-nilai kooperatif. Disimpulkan bahwa masyarakat Indonesia rentan mengalami keretakan yang berakibat pada kehancuran modal sosial kepercayaan (trust). Disarankan pentingnya revitalisasi nilai-nilai budaya lokal serta dukungan kebijakan tata kelola konflik yang inheren.
\end{abstract}

Kata Kunci: Modal sosial, Trust, Konflik Relasi sosial, Etnik, Penerimaan sosial

\begin{abstract}
Social reality is always inseparable from conflicts and tensions in social relations. This paper aims to describe two case studies, namely the social life of the people of Poso after the conflict and social relations between ethnic groups in Biak, Papua, which were studied quantitatively and qualitatively. The results of the study found that the factual Poso people are still bound by memories of past conflicts which hinder the true peace process. Meanwhile, social relations between indigenous and immigrant ethnic groups in the Biak Papua land also experience social tensions as a result of economic competition, thus destroying cooperative values. It is concluded that Indonesian society is prone to cracks which result in the destruction of the social capital of trust (trust). It is suggested the importance of revitalizing local cultural values as well as support for inherent conflict governance policies.
\end{abstract}

Keywords: social capital, trust, social relations conflict, ethnicity, social acceptance 
Jurnal Predestination: jurnal of Society and Culture.

Vol .1 No.2, Maret 2021

\section{PENDAHULUAN}

Disadari atau tidak kita sering berada pada kondisi konflik dengan orang lain baik karena alasan personal maupun karena ada sangkut-pautnya dengan kelompok. Begitu pula pada kehidupan sosial yang begitu luas, konflik tidak dapat dipisahkan dari kehidupan bermasyarakat yang terjadi secara berulang, berpola dan menghasilkan multi konsekuensi. Maka wajar dikatakan jika masyarakat adalah sebuah arena konflik. Masyarakat (Nusantara) multi kultur ini faktual masih menyimpan bara api konflik.

Penelitian terbaru menunjukan bahwa kehidupan sosial lekat dengan konflik. Seperti konflik komunal yang melibatkan pemeluk agama Islam dan Kristen di Poso (1999-2001). Uniknya, meski konflik terbuka telah berakhir, namun tragedi kemanusiaan dimasa lalu masih menyisahkan bara api konflik sampai saat ini. Secara garis besar, rekonsiliasi konflik Poso menemui kegagalan serius, setidaknya disebabkan oleh dua faktor utama yaitu, keterikatan masyarakat pada kondisi masa lalu dan kekhawatiran masyarakat pada kondisi sosial masa kini (eksisting) yang mengancam perdamaian (Nutfa et al., 2016).

Kondisi ditempat lainnya seperti di Biak Numfor Provinsi Papua, juga memperlihatnya potret relasi sosial sarat konflik. Seperti konflik atas perebutan sumber daya pasar yang melibatkan antar etnik lokal dengan etnik luar (pendatang). Pada konteks ini pasar di lihat sebagai arena kompetisi antar pedagang dalam memperebutkan sumber daya (fasilitas pasar). Sehingga kompetisi yang dibungkus oleh kecemburuan sosial pada akhirnya memicu konflik berbau etnik (Laha et al., 2016). Jika sudah demikian, mampukah social trust terus berlangsung ditengah masyarakat?

Apalagi konflik yang banyak ditemui di Indonesia adalah konflik horizontal yaitu konflik etno religius yang bersifat komunal, laten dan masih terus mengakar di masyarakat (Trijono, 2004). Laporan penelitian lain menyimpulkan terdapat kecenderungan bahwa konflik di nusantara adalah konflik komunal berbasis isu agama dan kompetisi etnis. Pengalaman dimanapun, konflik berlatar etno religius rentan bertransformasi menjadi konflik kekerasan dan menarik keterlibatan aktor lintas regional dan sangat sulit diselesaikan (Pamuji et al., 2008).

Namun kekhawatiran penulis sebagaimana dibahas dalam tulisan ini justru tertuju pada konsekuensi yang timbul dari konflik, yaitu hancurnya modal sosial dalam bentuk rasa kepercayaan (social distrust) ditengah masyarakat. Menurut D. Cohen dan L. Prusak dalam (Hasbullah, 2006), modal sosial merupakan setiap pola hubungan yang diikat oleh kepercayaan (trust), kesalingpengertian (mutual understanding), dan nilai-nilai besama (share value). Fungsinya untuk menyatukan anggota kelompok agar mampu bekerjasama secara efisien dan efektif

Sedangkan kepercayaan (trust) adalah ukuran signifikan dari social capital. Tetapi social trust di Indonesia telah mengalami kemerosotan sejak lama (Fukuyama, 2002). Kemerosotan modal sosial trust itu dapat dilihat pada kasus-kasus kekerasan massa, konflik, maupun krisis politik seperti pada tahun 1998-1999.

Pada konteks konflik sosial, semakin lama konflik berlangsung, semakin cepat hilangnya rasa kepercayaan sebagai modal sosial utama membagun perdamaian sejati. Hilangnya rasa kepercayaan (social distrust) berarti hilangnya rasa percaya masyarakat pada negara dan kepada sesama masyarakat (Nutfa \& Anwar, 2015). Apakah karena alasan konflik berkepanjangan, kekaburan tindakan hukum, atau akibat dari kuatnya determinasi ekonomi politik di tingkat local - tetapi faktual, konflik telah menghancurkan trust.

Konflik komunal di bagian timur Indonesia seperti terjadi di Poso, Papua dan Maluku Utara adalah bukti bahwa nilai-nilai social trust telah hancur lebur. Bahkan sebelum konflik 
Jurnal Predestination: jurnal of Society and Culture.

Vol .1 No.2, Maret 2021

terjadi, social trust mulai memudar seiring mengakarnya konflik sosial. Konflik di Halmahera Utara (1999), menjadi contoh lain bagaimana harmonisasi antar komunitas Islam dan Kristen di luluhlantakan oleh konflik yang dipolitisasi seakan sebagai konflik SARA sebagaimana halnya terjadi di Poso (Cangara, 2013).

Kehancuran trust diwilayah-wilayah bekas konflik membuat resolusi dan rekonsiliasi konflik tidak lagi menjadi obat penawar ampuh, sebab konflik terlanjur mengakar (latensi) sejak masa lama. Sebab penyelesaian konflik cenderung top down, minimnya sarana-sarana rekonsiliasi dan kebijakan rekonsiliasi konflik belum sistematis (Trijono, 2007). Maka kegagalan negara adalah pada kegagalan menanamkan rasa kepercayaan masyarakat (social trust) secara membumi. Negara dan perangkatnya tidak mampu membalikan keadaan harmoni total sebagaimana sebelumnya. Itulah mengapa kepuasan damai sulit di capai, bahkan menjadi rentan konflik.

(Fukuyama, 2002), dalam karyanya Trust: Kabajikan Sosial dan Penciptaan Kemakmuran mengatakan kepercayaan (trust) sebagai modal sosial yang sangat penting bagi kehidupan bermasyarakat. Kehilangan trust berarti kehancuran modal sosial, sebab, ia adalah norma-norma dan nilai-nilai bersama yang mengikat hubungan antar orang, bahkan menentukan kehidupan ekonomi negara. Kehilangan trust berarti pula menanggung biaya ekonomi yang tinggi.

Selain menjadi pengikat solidaritas, trust adalah faktor ideal yang dapat mencegah pertikaian dan sengketa, trust juga menjadi atribut kolektif untuk mencapai tujuan bersama. Karena trust sesungguhnya tumbuh dan berakar dari nilai-nilai budaya setiap masyarakat, (Fukuyama, 2002) (Hasbullah, 2006). Sebab diyakini, tidak satupun kelompok masyarakat yang terus-menerus ingin hidup dalam suasana konflik. Bagaimanapun caranya benih-benih perdamaian akan tumbuh meskipun berjalan lambat.

Menumbuhkembangkan kembali akar-akar social trust yang masih tersisa di masyarakat akan mempercepat laju perdamaian sejati meskipun konflik telah menghancurkan modal social - trust yang lama. Hanya dengan merekonstruksi social trust baru kedalam sebuah program rekonsiliasi konflik, diyakini akan menciptakan kembali perdamaian sejati melalui: (1) program asosiasi untuk menghindari sikap individualistik; (2) program berorientasi kerjasama agar menumbuhkan rasa memiliki bersama; (3) menanamkan sikap jujur agar tidak oportunistik; dan (4) menanamkan sikap loyalitas demi kepentingan kolektif (Nutfa \& Anwar, 2015).

Social trust merupakan salah satu modal sosial dalam pencegahan dan penyelesaian konflik dimanapun. Tertanamnya kembali rasa kepercayaan di jiwa masyarakat akan memberikan keuntungan besar bagi kesejahteraan bersama, yaitu terciptanya rasa aman, nyaman, kedamaian dan keharmonisan dan terbuka untuk saling memaafkan sehingga dapat saling menerima seperti semula. Ketika derajat kepercayaan yang tinggi tercapai, masyarakat akan merasa betah untuk kembali hidup berdampingan.

\section{METODE}

Tulisan ini merupakan telaah dan pengembangan lanjut dari hasil penelitian lapangan di tahun 2015-2020 yang dilakukan penulis di Kabupaten Poso Sulawesi Tengah dan di Kabupaten Biak Numfor Papua. Untuk lokus penelitian di Poso dilakukan pada dua komunitas agama, yaitu Komunitas Islam di Kecamatan Poso Kota dan Komunitas Kristen di Kecamatan Pamona Puselemba (Tentena) untuk menganalisis kelangsungan rekonsiliasi pasca konflik yang dilihat dari tingkat penerimaan sosial antar pemeluk agama. 
Jurnal Predestination: jurnal of Society and Culture.

Vol .1 No.2, Maret 2021

Penulis menggunakan desain penelitian mix method dengan pendekatan triangulasi konkuren (Creswell, 2014). Adapun sampel dalam penelitian ini sebanyak 104 responden dan informan sebanyak 9 orang yang di pilih secara purposive untuk mendalami data kualitatif. Pengumpulan data diawali dengan metode survei (kuantitatif) dan kemudian dilengkapi dengan data kualitatif melalui wawacara mendalam dan observasi terbatas.

Sementara, penelitian mengenai dampak konflik penguasaan sumber daya pasar terhadap relasi sosial antar pedagang dilakukan di lingkungan pasar ikan Kelurahan Fandoi Distrik Biak Kota Kabupaten Biak Numfor. Metode yang digunakan adalah diskriptif dengan pendekatan studi kasus, dengan maksud untuk menggali motif yang melatarbelakangi penguasaan sumber daya pasar dan menginterpretasi perilaku konflik antar pedagang etnik lokal (Biak) dengan pedagang etnik luar (Jawa, Buton dan Bugis) sebagai unit analisis. Data diperoleh melalui observasi terbatas, wawancara dan diskusi kelompok dengan melibatkan 8 orang narasumber yang dipilih secara purposive.

\section{HASIL DAN PEMBAHASAN}

\section{A. Hasil Penelitian \\ 1. Penerimaan Sosial yang Hilang: Kasus Konflik Poso}

Hasil penelitian menunjukan bahwa pasca konflik, penerimaan sosial antar kedua kelompok agama memiliki derajat penerimaan sosial yang tidak sama. Kelompok yang merasa memiliki korban terbanyak (Muslim), masih menyimpan traumatik dan mengalami ketidakpuasan damai sehingga lebih sulit menerima kelompok lainnya (out group) untuk kembali melebur kedalam satu wilayah yang sama.

Penerimaan tampat ibadah adalah pilihan penerimaan yang sangat sulit. Karena tempat ibadah dianggap sebagai salah satu simbol kolektif kelompok/komunitas. Meskipun seseorang secara personal diterima oleh suatu kelompok agama dalam relasi sosial sehari-hari, tetapi secara simbolik kolektif ia belum tentu atau akan sulit diterima. Jadi, toleransi keagamaan dalam bentuk penerimaan sosial nampaknya masih sulit diwujudkan sebagaimana keadaan sebelum pecahnya konflik.

\section{a. Pemisahan In Group dan Out-Group}

Pasca konflik, kehidupan kedua komunitas agama ini semakin nyata terpisah dan cenderung sulit untuk dilebur kembali. Segregasi wilayah turut berimbas pada segregasi kehidupan sosial. Akar masalah sesungguhnya bukan mengenai perbedaan agama, tetapi rasa was-was menjadikan kepercayaan antar orang lain menjadi rendah bahkan hilang. Apalagi, kondisi sosial Poso yang identik dengan serangan dan ancaman kekerasan (teror), serta ketidakpastian jaminan keamanan semakin memperburuk kondisi lokal.

Secara kasat mata kondisi masyakat Poso kelihatan teratur, tenang dan damai. Tetapi sesungguhnya kondisi itu selalu berubah-ubah. Meskipun ada banyak kantong-kantong militer (TNI dan Polri) tetapi sama sekali tidak menghadirkan rasa aman dan nyaman yang tinggi. Apalagi sebagian besar masyarakat Poso tidak lagi menaruh kepercayaan penuh pada institusi keamanan itu, karena luka masa lalu masih membekas. Banyak perempuan-perempuan Poso yang justru menjadi korban "cinta palsu" aparat keamanan dimasa pengendalian konflik.

Berangkat dari kondisi itulah tumbuh perasaan ketidaksiapan penerimaan sosial antar kedua kelompok agama sehingga cenderung menarik diri untuk tidak lagi saling melebur dalam satu wilayah atau lingkungan sosial yang sama. Sebagaimana dikatakan narasumber Bapak B (56 tahun): "Menjadi masyarakat Poso bisa ditoleransi, hanya kalau misal hidup satu kompleks 
Jurnal Predestination: jurnal of Society and Culture.

Vol .1 No.2, Maret 2021

seperti disini saya belum siap...Sulit juga bagi mereka untuk kembali kemari" (wawancara 13 Oktober 2015).

Pasca konflik masyarakat Poso memilih hidup dalam bingkai segregasi. Kondisi ini pula membuat penerimaan sosial memiliki kualitas berbeda. Karena kekhawatiran untuk kembali hidup dalam satu lingkungan yang sama telah memperlebar jarak sosial dan jarang kepercayaan. Jadi, hambatan penerimaan sosial pada kedua kelompok ini adalah dalam bentuk penolakan untuk melebur menjadi satu kelompok kolektif sebagaimana sebelum konflik.

\section{b. Ingatan Masa Lalu yang Membekas}

Sudah dua dasawarsa tragedi kemanusiaan di Poso berlalu. Tetapi ingatan konflik tidaklah lenyap seiring bergulirnya waktu. Anak - anak yang dulunya (1999-2001) menjadi korban - dampak konflik, saat ini mereka telah dewasa dan mengerti keadaan masa lalu. Dua puluh tahun silam, anak-anak itu berlari ketakutan ketika mendengar suara ledakan bom, teriakan histeris, melihat kobaran api, mayat-mayat, bahkan ada yang menjadi korban pembunuhan sporadis.

Tragedi konflik Poso sampai hari ini masih membekas dalam ingatan penduduk setempat. Seperti pengakuan Ibu IFW (30 tahun), salah seorang narasumber eks pengungsi/korban kerusuhan Poso berikut:

"Saat itu menjelang subuh, saya dan saudara saya dibangunkan oleh papa yang bilang ada musuh datang masuk menyerang ke kompleks kami. Seketika, mama mengumpulkan kami berenam, lalu mengajak lari menuju pantai dan hanya membawa pakaian dibadan saja. Papa berteriak; 'mereka (musuh) sudah dekat, cepat lari...' papa masih sempat memegang tangan saya dan dua adik saya. Mama juga memegang tangan kakak. Namun, musuh terlanjur dekat, mereka sudah mulai kelihatan mengejar. Orangorang sudah ada yang terbunuh, saya mendengarnya karena ada yang berteriak menjerit. Tanpa sengaja saya terlepas dari tangan papa dan jauh dari jangkauan mama. Saat itu saya terpisah. Kemudian tangan saya dipegang paman saya. Dia menyembunyikan saya di parit lalu menutupnya dengan dahan mangga. Saya kemudian melihat paman ditebas lalu mati. Beruntung saya selamat (wawancara, 23 Januari 2016, Kota Poso).

Selama kerusuhan berlangsung, mulut anak-anak itu bungkam karena takut dan trauma. Namun bukan berarti ingatan tentang pengalaman mengerikan itu hilang begitu saja. Banyak dari anak-anak korban konflik Poso yang hari ini mereka telah dewasa, namun peristiwa kelam itu masih membekas di ingatan.

Narasumber lain adalah MRN (44 tahun) juga memiliki ingatan masa lalu, MRN mengatakan:

"Sudah pasti teringat kerusuhan saat melihat sisa-sisa bangunan terbakar. Biar bagaimana pun itu (konflik) pernah terjadi, dan lama....Pokoknya semua Kota Poso ini masih ada tersisa" (wawancara pada 20 September 2015).

Banyaknya sisa-sisa bangunan terbakar di Kota Poso memberi kesan traumatik bagi masyarakat setempat. Ini membuktikan jika rekonsiliasi konflik belum sepenuhnya menghapus ingatan masa lalu.

\section{c. Ketidakpuasan Damai}

Selain traumatik konflik, rasa ketidakpuasan berdamai menjadi masalah subtansial. Pengakuan seorang narasumber M (31 tahun), bahwa menurutnya hingga saat ini kepuasan berdamai atas prakarsa pemerintah belum sepenuhnya dirasakan masyarakat Poso. Dengan 
Jurnal Predestination: jurnal of Society and Culture.

Vol .1 No.2, Maret 2021

wajah berapi-api ia mengungkapkan kekesalannya terhadap pemerintah yang dinilai gagal dalam melakukan upaya damai:

"Untuk dendam sudah tidak. Hanya tidak puas dengan perdamaian...Perjanjian damai yang di buat oleh pemerintah hanyalah kepentingan uang (proyek). Pihak yang menyelesaikan tidak mewakili keinginan perdamaian saya" (wawancara 17 September 2015).

Sebagian masyarakat Poso menilai bahwa rekonsiliasi konflik belum benar-benar mampu mendamaikan masyarakat dan belum memberi tindakan-tindakan yang membuat masyarakat merasa puas terhadap perdamaian.

Jadi, dengan belum terpenuhinya rasa kepuasan berdamai secara pribadi serta model rekonsiliasi pemerintah yang dinilai bermuatan kepentingan, telah menimbulkan rasa ketidakpercayaan (distrust) masyarakat terhadap pemerintah dalam upaya penanggulangan kehidupan sosial pasca konflik. Sehingga kesan traumatik konflik dan ketidakpuasai damai masih mengakar dimasyarakat Poso sampai hari ini.

\section{Perebutan Sumber Daya Pasar antar Etnik Pribumi dan Pendatang di Biak}

a. Sejarah Relasi Komin dan Amber

Komin dalam bahasa lokal adalah etnik pribumi Biak, sedangkan Amber istilah untuk etnik pendatang. Beberapa sumber menjelaskan bahwa relasi sosial antar penduduk pribumi (Komin) dengan pendatang (Amber) sudah berlangsung sejak abad ke-16, baik alasan perdagangan maupun ekspedisi perang kerajaan. Konon etnik Biak sudah menjelajah sampai ke Maluku Utara dan Papua sebelum masuknya kolonial. Dimasa itu etnik Biak sudah membangun relasi kerjasama (sekutu) dengan Kesultanan Tidore. Itulah awal dari tumbuhnya ikatan sosial, terutama diperkuat oleh perkawinan campur, sehingga terbagun solidaritas antara etnik pribumi (Komin) dan etnik luar (Amber) yang diikat oleh sistem marga.

Terbangunnya relasi sosial antara Komin dengan Amber mulai mengubah tatanan prekonomian dan pola hidup masyarakat lokal etnis Biak, terutama ketika mereka hidup secara multikultur dipesisir Biak. Kehidupan multikultur ini diiringi dengan kehidupan ekonomi yang menciptakan relasi ekonomi yang kompetitif. Disaat itu pula Komin mulai menggantungkan diri pada komoditas pasar. Transformasi ekonomi yang begitu tajam terjadi sejak pertangahan tahun 1960-an.

Namun seiring bertambahnya jumlah penduduk kota maka semakin kental persaingan sosial ekonomi antar etnik. Akibatnya etnis lokal Biak sulit untuk bersaing dengan etnis pendatang yang memiliki spirit kompetisi tinggi. Sementara penduduk pribumi cenderung stagnan, apalagi tingkat kesejahteraan ekonominya rendah. Melihat persaingan ekonomi yang ketat, maka Pemerintah Daerah Biak mengambil kebijakan dengan menyediakan sumber daya pasar seperti lapak-lapak, kios, serta pemberian bantuan tunai kepada pedagang etnis lokal (Komin) khususnya pada marga Rumkorem, Randongkir, Kabarek dan Rumbiak di Pasar Ikan Kelurahan Fandoi.

\section{b. Munculnya Kompetisi antar Pedagang Komin dan Amber}

Diawali dari kebiasaan pedagang Komin yang sering berpindah-pindah berjualan, dari lapak atau kios didalam pasar, bergeser ke pinggir jalan. Ada pula dari pedagang Komin yang sengaja menyewakan dan menjual kios ke pedagang Amber (Jawa, Buton, Maluku dan Bugis). Seorang pedagang Amber, SVA menjelaskan bahwa: 
Jurnal Predestination: jurnal of Society and Culture.

Vol .1 No.2, Maret 2021

"Kios dan lapak-lapak ini dulunya orang sini (lokal) yang punya. Dari Pemerintah yang sediakan, awal-awal itu mereka berdagang tetapi lama-lama mereka jual dan di sewakan pada kami orang pendatang" (Wawancara 08 September 2020).

Hasil penelitian menujukan bahwa terdapat konsekuensi persaingan antara pedagang Komin dan Amber. Kompetisi yang dimaksud adalah perebutan sumber daya pasar. Kompetisi terjadi ketika pedagang pribumi (Komin) selalu merasa tersaingi oleh pedagang Amber seperti soal kepemilikan modal usaha, keuletan dan sumber daya pasar. Pihak Dinas Perikanan dan Kelautan Biak Numfor mengatakan bahwa fasilitas pasar sesungguhnya diperuntukan lebih kepada pedagang pribumi, namun karena mereka tidak memiliki modal yang cukup maka fasilitas sumber daya pasar jatuh ketangan pedagang etnik pendatang (Amber).

Modal rupanya menjadi penentu kekuatan kompetisi antar pedagang yang berarti semakin besar modal yang dimiliki maka semakin kuat dalam bersaing. Menyadari lemah dalam persaingan ekonomi, pedagang etnik lokal menganggap mereka kalah bersaing. Mereka tidak mempersepsikan persaingan sebagai tenaga yang memotivasi kreativitas dan semangat kerja. Sebaliknya, persaingan itu malah diartikan sebagai proses penyingkiran mereka sebagai pribumi.

Sebagai pribumi mereka kemudian menunjukan kekecewaan terhadap otoritas (pemerintah) pasar yang dinilai tidak berlaku adil dalam distribusi sumber daya pasar. Kekesalan itu kemudian diarahkan pada para pedagang Amber. Seperti pernyataan narasumber YHS, seorang pedagang Komin berikut ini:

"Penjual-penjual yang diluar sini tong (kami) mau bikin tempat jualan seperti yang ada didalam itu supaya kalo hujan atau panas itu tidak sengsara. Makanya kami yang jualan di trotoar sering jaga ribut-ribut dengan orang yang jualan di dalam itu, apalagi yang datang jualan di sini baru dapat tempat yang sudah di tempati itu tetap mereka baku ribut. Ada ibu yang biasa tong (kami) panggil dia ibu pasar itu yang sering baku ribut dengan pedagang lain. (Wawancara 02 Oktober 2020).

Kompetisi yang terjadi di pasar ikan Kelurahan Fandoi merupakan konsekuensi logis dari sebuah masyarakat multikultur. Masyarakat pribumi Biak merasa sulit dan kalah dalam persaingan perebutan sumber daya pasar terutama karena faktor rendahnya etos kerja dan ketersediaan modal yang rendah dibanding pedagang pendatang. Jadi, dalam konteks ini pasar dipandang sebagai sebuah institusi multikultural dan sarat dengan berbagai persaingan dan konflik.

\section{c. Dari Dominasi Menjadi Akar Konflik}

Dominasi yaitu keadaan di mana seseorang atau sekelompok orang ingin menguasai orang lain baik pemikiran, ide atau bahkan proses kehidupan kelompok lain. Hasil penelitian menunjukan bahwa sumber daya pasar cenderung di dominasi oleh para pedagang etnis pendatang (Amber). Karena merasa termarjinalkan, pedagang lokal etnis Biak tidak menerima keadaan, sebagaimana pernyataan informan MB berikut:

"Pedagang pendatang yang lebih menonjol sebenarnya kami sangat tidak terima. Kami yang asli pedagang dari papua ini sebenarnya kami yang harus menempati pasar yang kami punya. tapi kenapa orang pedatang yang lebih banyak punya tempat-tempat jualan? Itu karna uang mereka bayak" (Wawancara 3 Oktober 2020).

Pernyataan di atas menjelaskan beberapa hal: pertama, dalam konteks dominasi sumber daya pasar dan penolakan etnis lokal, aroma sukuisme kental tercium. Kedua, Alat 
Jurnal Predestination: jurnal of Society and Culture.

Vol .1 No.2, Maret 2021

utama dalam proses dominasi sumber daya kapital yang dimiliki oleh pedagang. Tanpa kapital, sumber daya pasar tidak akan dikuasai. Ketiga, secara prediktif, kontradiksi yang termuat dalam pernyataan di atas bisa menjadi bom waktu bagi lahirnya konflik yang lebih besar. Disimpulkan bahwa dominasi sumber daya pasar oleh etnis pendatang (Bugis, Buton, Maluku Utara, Ambon, Jawa, dll.) didorong oleh tiga aspek yaitu, skill, kapital dan solidaritas okupasi.

Kesenjangan ekonomi yang tajam menimbulkan rasa kecemburuan sosial antar pedagang Komin dan Amber. Ketika pedagang etnis lokal sulit beradaptasi dengan lingkungan dan perkembangan sosial ekonomi, mereka pertahanan diri (self defence) melalui simbolsimbol komunikasi tertentu, seperti perilaku kekerasan, ancaman verbal, bahkan menerapkan solidaritas in-group dan out-group. Kesenjangan itu menciptakan konflik dalam kelas sosial, meskipun cenderung laten. Konflik terbuka mulai menggejala dalam ekspresi para pedagang lokal sehari-hari. Contohnya cibiran-cibiran, baik secara halus maupun terang-terangan sebagai bentuk antipati mereka terhadap para pedagang pendatang (Amber).

\section{B. Pembahasan}

Konflik Poso telah membuktikan ketika terjadi disharmoni dan melemahnya ikatan sosial, akan lahir sejarah baru dimana tatanan sosial telah runtuh oleh keterpisahan sosial (social segreration) sebagai akibat dari konflik. Tatanan sosial seperti ikatan-ikatan primordial, kekerabatan, kekeluargaan, moralitas, kepercayaan, norma-norma kooperatif serta nilai-nilai sosial lokal yang menjadi modal sosial (social capital) masyarakat banyak mengalami kehancuran besar (the great disruption). Hancurnya tatanan sosial adalah hancurnya sebuah modal sosial (Fukuyama, 2002).

Konflik telah mengobrak-abrik kemapanan struktur sosial yang pada kehancuran modal sosial (social capital) lokal sebagai akibat dari konflik komunal sehingga masyarakat kehilangan dari apa yang seharunya menjadi kekuatan harmonisasi sosial. Modal sosial yang dimaksud adalah sumber daya yang dapat ditanamkan untuk mendapatkan kembali sumber daya baru yang dapat dikonsumsi, disimpan dan diinvestasikan (Hasbullah, 2006).

Modal sosial merupakan sumber daya diharapkan bersifat memulihkan tatanan sosial yang telah hancur pasca konflik, terutama modal sosial trust (kepercayaan) yang diyakini mampu menghidupkan dan membangun kembali sistem kekerabatan dan rasa kekeluargaan dalam menemukan kembali bagian-bagiannya yang telah terpisah dan hancur akibat konflik (Fukuyama, 2002).

Namun pada akhirnya kondisi masyarakat Poso pasca konflik masih belum menemukan formulasi trust karena tingginya faktor hambatan rekonsiliasi (traumatik dan ketidakpuasan damai) sehingga rendahnya tingkat penerimaan sosial antar dua kelompok agama. Lewis A. Coser dalam (Poloma, 2007), melihat konflik sebagai proses sosial yang mampu mempersatukan kehidupan sosial. Menurutnya konflik memiliki sisi positif yaitu memperkuat struktur sosial dan menjadi instrumen untuk menyatukan suatu kelompok tertentu (in-group) untuk menentang kelompok lain (out-group).

Konflik non-realistis ala Coser menggambarkan kehidupan sosial masyarakat Poso pasca konflik dimana banyak terjadi kasus pembuhan misterius, pemboman, penembakan misterius, kekerasan terhadap warga sipil dan kekerasan/teror terhadap aparat keamanan. Uniknya, multipihak saling mengkambinghitamkan pihak lain ketika kasus-kasus misterius itu muncul dipermukaan. Itulah mengapa persoalan konflik Poso masih menyisakan banyak persoalan yang tidak tampak dipermukaan (laten). 
Jurnal Predestination: jurnal of Society and Culture.

Vol .1 No.2, Maret 2021

Berkembangnya stereotip dan prasangka sosial pada setiap kelompok dalam (in-group) ini membuat hubungan sosial dengan kelompok luar (out-group) semakin menjauh serta semakin mempertegas batasan kelompok dan memperkuat kohesi sosial masing-masing kelompok. Menurut Coser kondisi demikian menggambarkan masih menguatnya konflik nonrealistis, terutama akan terus berkembang ketika adanya dendam lama yang kemudian diarahkan kepada objek atau kelompok lain melalui pengkambinghitaman maupun prasangkaprasangka sosial (Poloma, 2007)

Jika pada masyarakat Poso pasca konflik masih menemui jalan buntu damai yang menyulitkan penerimaan sosial kelompok, lain halnya dengan masyarakat Biak Papua yang mengalami ketegangan relasi sosial akibat dari ketidakharmonisan antar etnik lokal (Komin) dengan etnik pendatang (Amber). Uniknya ketegangan sosial ini berlangsung dalam arena sosial yang heterogen yaitu tempat pertukaran ekonomi yaitu pasar ikan di Kelurahan Fandoi.

Menurut teori persaingan, heterogenitas akan melahirkan persaingan (competition) dalam perebutan suatu sumber daya terbatas. Bahkan menurut Robert Park bahwa manusia memiliki jiwa kompetisi untuk mendapatkan sumber daya alam yang tersedia. Di samping itu, tradisi ekologi manusia mengajarkan bahwa manusia harus berjuang, bersaing untuk bisa bertahan hidup (LIliweri, 2005).

Hasil penelitian ini dapat dibandingkan dengan penelitian (Riyanti, 2013), relasi sosial antara pedagang etnis Cina dan pedagang etnis Jawa di pasar Purwareja Klampok Banjarnegara mencerminkan dua bentuk relasi sosial yatu relasi di pasar dan diluar pasar. Temuannya, bahwa relasi diluar pasar memperlihatkan adanya jarak sosial yang cenderung dipengaruhi oleh faktor etnisitas. Sebaliknya, relasi dalam pasar menunjukan hubungan egalitarian. Uniknya, meskipun kedua kelompok etnik ini hidup berdampingan secara tentram karena saling diuntungkan secara ekonomis, tetapi stereotype etnis justru eksis dan masih berkembang sehingga cukup mempengaruhi hubungan sosial dalam kehidupan sehari-hari.

Relasi sosial yang dilakukan antara pedagang etnis Cina dan pedagang etnis Jawa di pasar Purwareja Klampok yaitu baik di dalam pasar, maupun di luar pasar masih terlihat adanya jarak sosial yang lebih banyak dipengaruhi oleh etnisitas. Tetapi relasi sosial yang terbangun antara pembeli dan pedagang di pasar Purwareja Klampok, Banjarnegara tidak membedakan adanya perbedaan etnis. Dalam kehidupan bermasyarakat, etnis Cina dan etnis Jawa hidup berdampingan dengan baik, keduanya saling diuntungkan secara ekonomis. Namun stereotype etnis diantara keduanya masih tetap ada dan berkembang dalam masyarakat yang cukup mempengaruhi hubungan sosial kedua etnis dalam kehidupan sehari-hari.

Hasil penelitian menunjukan pula bahwa faktor penting pendorong ketegangan relasi sosial antara Komin dan Amber ini salah satunya dipicu perasaan cemburu dan adanya kesenjangan tertentu. Menurut Maurice dalam (Irawati et al., 2001) kecemburun sosial dan kesenjangan akan menciptakan konflik dalam kelas sosial antara kelas mendominasi dan kelas yang di dominasi. Tetapi kondisi ini suatu kewajaran, terutama disektor informal. Apabila konflik terjadi itu kerena pesaing tidak hanya dengan sengaja mencampuri pihak lain, tetapi karena ikut serta melibatkan diri pada persoalan pihak lain.

Dari dua penelitian ini dipahami bahwa konflik dan ketegangan relasi sosial telah menghilangkan nilai-nilai kolektifitas dimana persatuan dikalahkan oleh potensi-potensi disintegrasi. Rapuhnya kekuatan integrasi sosial membawa kita pada suasana distrust (ketidakpercayaan) berkepanjangan. Maka rekonstruksi modal sosial trust merupakan sebuah keharusan sosial guna membangun kembali tatanan sosial berbasis perdamaian. Caranya adalah melalui pelembagaan (institutionalization) perilaku yang mengarah pada kejujuran, rasa saling percaya, saling membantu, jaringan sosial, dan kepedualian sosial, sehingga tercapai kodisi masyarakat dengan tingkat penerimaan sosial (toleransi) yang tinggi dan setara. 
Jurnal Predestination: jurnal of Society and Culture.

Vol .1 No.2, Maret 2021

\section{KESIMPULAN}

Kehidupan masyarakat Poso pasca konflik memperlihatkan potret kehidupan yang sejatinya masih dihantui bayang-bayang (konflik) masa lalu, sehingga proses perdamaian sejati berjalan lambat dan semakin tertinggal oleh runtuhnya modal sosial kepercayaan baik secara horizontal (terhadap out group) maupun vertikal (terhadap beberapa institusi negara). Begitu pula dengan ketegangan relasi sosial antar etnik pribumi dengan etnik pendatang di tanah Biak Papua yang mengalami keretakan akibat daya kompetisi ekonomi yang mematikan nilai-nilai kooperatif dari kedua kelompok.

Dua kenyataan ini menandai rendahnya tingkat kepercayaan dan sempitnya radius kepercayaan pada tatanan masyarakat Indonesia saat ini. Olehnya itu penting untuk revitalisasi dan rekonstruksi nilai-nilai budaya damai berbasis modal sosial trust yang dipadukan dengan human capital. Suatu kebijakan tata kelola konflik yang mensinergikan antara social capital dengan human capital diyakini mampu membentuk sebuah masyarakat ideal dengan tingkat kepercayaan tinggi dan radius kepercayaan yang luas sehingga mampu mencapai derajat penerimaan sosial yang setara.

\section{DAFTAR PUSTAKA}

Cangara, S. (2013). Iii 41. SOCIUS: Jurnal Sosiologi, 2013, XIV, 41-47.

F Fukuyama. (2002a). Trust: kebajikan sosial dan penciptaan kemakmuran. Qalam.

F Fukuyama, R. (2002b). The great disruption: hakikat manusia dan rekonstitusi tatanan sosial. Qalam.

Irawati A. dkk. (2001). Kerusuhan Sosial di Indonesia. PT Gramedia Widiasarana.

J Hasbullah. (2006). Social capital: Menuju keunggulan budaya manusia Indonesia. MRUnited Press.

JW Creswell. (2014). Research Design Pendekatan Kualitatif, Kuantitatif, dan Mixed Edisi Ketiga. Pustaka Pelajar.

L Trijono. (2004). Potret retak Nusantara: studi kasus konflik di Indonesia. Yogyakarta.

L Trijono. (2007). Pembangunan sebagai perdamaian: rekonstruksi Indonesia pasca-konflik. books.google.com.

Laha, M.S., Kasnawi, M.T., R. A. (2016). Dampak Perebutan Sumber Daya Pasar Terhadap Relasi Sosial Antar Pedagang. Jurnal Analisis, 5 No. 2.

LIliweri, A. (2005). Prasangka\&Konflik Komunikasi Lintas Budaya Masyarakat Multikultural. PT LKIS Pelangi Aksara.

M Pamuji, H Nanang, G Miqdad, L. S. (2008). Success Story Mekanisme Komunitas dalam Penanganan dan Pencegahan Konflik: Studi kasus di Desa Wayame (Ambon) dan Desa Tangkura (Poso). FES.

Nutfa, M., \& Anwar, S. (2015). Membangun Kembali Perdamaian: Rekonsiliasi Konflik Komunal Berbasis Trust. Kritis, 1(1), 133-142.

Nutfa, M., Pulubuhu, D. A. T., \& Cangara, S. (2016). Kegagalan Rekonsiliasi Masyarakat Poso Pasca Konflik Komunal. Jurnal Analisis, 5(2), 168-174.

Poloma, M. M. (2007). Sosiologi Kontemporer. PT. Raja Grafindo Persada.

Riyanti, P. (2013). Relasi Sosial Pedagang Etnis Cina Dan Etnis Jawa Di Pasar Tradisional. Komunitas: International Journal of Indonesian Society and Culture, 5(1), 53-63. https://doi.org/10.15294/komunitas.v5i1.2373 